This item was submitted to Loughborough's Research Repository by the author.

Items in Figshare are protected by copyright, with all rights reserved, unless otherwise indicated.

\title{
Energy-led domestic retrofit: impact of the intervention sequence
}

PLEASE CITE THE PUBLISHED VERSION

http://dx.doi.org/10.1080/09613218.2014.996360

PUBLISHER

(c) The Author(s). Published by Taylor \& Francis.

VERSION

VoR (Version of Record)

\section{PUBLISHER STATEMENT}

This work is made available according to the conditions of the Creative Commons Attribution 4.0 Unported (CC BY 4.0) licence. Full details of this licence are available at: http://creativecommons.org/licenses/by/4.0/

\section{LICENCE}

CC BY 4.0

\section{REPOSITORY RECORD}

Simpson, Sophie, Phil Banfill, Victoria Haines, Becky Mallaband, and Val Mitchell. 2015. "Energy-led Domestic Retrofit: Impact of the Intervention Sequence". Loughborough University. https://hdl.handle.net/2134/16496. 


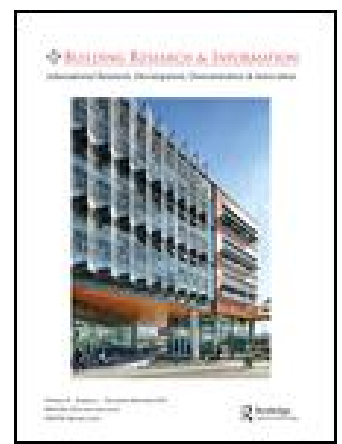

Building Research \& Information

\section{Energy-led domestic retrofit: impact of the intervention sequence}

\section{Sophie Simpson, Phil Banfill, Victoria Haines, Becky Mallaband \& Val Mitchell}

To cite this article: Sophie Simpson, Phil Banfill, Victoria Haines, Becky Mallaband \& Val Mitchell (2016) Energy-led domestic retrofit: impact of the intervention sequence, Building Research \& Information, 44:1, 97-115, DOI: 10.1080/09613218.2014.996360

To link to this article: https://doi.org/10.1080/09613218.2014.996360

$$
\begin{aligned}
& \text { (c) } 2015 \text { The Author(s). Published by Taylor \& } \\
& \text { Francis. }
\end{aligned}
$$

曲 Published online: 08 Jan 2015.

Submit your article to this journal

LII Article views: 2259

Q View related articles $\sqsubset$

View Crossmark data $₫$

Citing articles: 8 View citing articles 


\title{
RESEARCH PAPER
}

\section{Energy-led domestic retrofit: impact of the intervention sequence}

\author{
Sophie Simpson ${ }^{1}$, Phil Banfill', Victoria Haines ${ }^{2}$, Becky Mallaband $^{2}$ and Val Mitchell ${ }^{2}$ \\ ${ }^{1}$ School of the Built Environment, Heriot-Watt University, Edinburgh, UK \\ E-mails: s.a.simpson@hw.ac.uk and p.f.g.banfill@hw.ac.uk \\ ${ }^{2}$ Loughborough Design School, Loughborough University, Loughborough, UK \\ E-mails: v.j.haines@|lboro.ac.uk, r.mallaband@lboro.ac.uk and v.a.mitchell@|lboro.ac.uk
}

\begin{abstract}
Interviews conducted with householders reveal that energy efficiency is often a lesser motivation than other factors for undertaking home improvement work. Homeowners' approach to refurbishment is typically staged over several years, not as a whole-house retrofit. As the operational performance of an individual emission-reducing technology typically depends on what other measures are already in place, the retrofit intervention sequence can potentially affect the overall performance of the dwelling. The impact of the intervention sequence on a semi-detached 1930s' house is investigated with dynamic thermal modelling, using five sequences based on different homeowner personas developed from qualitative interviews. The results show that whilst a whole-house retrofit would reduce cumulative $\mathrm{CO}_{2}$ emissions over 25 years by $54 \%$, the sequences actually implemented by the individual households result in significantly smaller reductions of between $42 \%$ and $24 \%$. This variation in operational performance due to the intervention sequence means that there is a variable return on the investment for a particular technology and, significantly, that different sequences will yield different cumulative emission reductions. This has significant consequences for policies providing financial incentives for energy-led retrofit, particularly to include the intervention sequence and timing.
\end{abstract}

Keywords: consumer choice, energy, energy efficiency, homeowners, housing, low carbon, refurbishment, retrofit

\section{Introduction}

Reducing the carbon emissions associated with dwellings has a major role in achieving the UK government's target of an $80 \%$ reduction in the UK's carbon emissions by 2050 (HM Government, 2008). The domestic sector currently accounts for $29 \%$ of the UK's total energy consumption (DECC, 2014a), and by 2016 all new housing must be zero carbon (Carbon Zero Hub, 2013). However, this addresses only a small proportion of the domestic sector, because the UK has one of the oldest building stocks in the developed world (EST, 2007) and $75 \%$ of the housing predicted to be occupied in 2050 exists today (Wright, 2008).

Homes typically undergo just one major refurbishment every 50 years (EST, 2011a), so there is a restricted capacity to improve the efficiency of the existing stock by 2050. It is therefore important to understand the factors influencing a homeowner's decision to implement energy-efficiency measures, and to identify effective strategies to incorporate such measures during minor refurbishments.

The purpose of this paper is to consider the implications of installing a series of retrofit measures in different sequences for a case study dwelling, representative of a solid-wall, semi-detached house. It reports a building performance simulation exercise to investigate the effect on the building's energy consumption and $\mathrm{CO}_{2}$ emissions. The different retrofit sequences have been derived from interviews with occupants of similar dwelling types, based on their experiences of home improvement, and represent actual rather than notional intervention sequences. Simulation is the only feasible way to compare the effects of these different retrofit sequences. Following a review of relevant literature, a sample of householders was interviewed in-depth (Haines, Mitchell, \& Mallaband, 2012) and 
a set of personas developed from the analysed resulting data. Five of these 'archetype' personas (Haines \& Mitchell, 2014) were selected and householders from the sample that most closely represented the persona were identified. Dynamic building simulation software (IES Virtual Environment) was used to model a case study dwelling and then to consider the impact of the derived retrofit timelines on that dwelling's annual and cumulative performance over a 25 -year period.

This paper is structured as follows. The next section discusses the factors that influence homeowners' decisions to retrofit their home, and the role of policy and regulations in encouraging the uptake of efficiency measures. The following section analyses findings from interviews with homeowners of hard-to-treat dwellings and identifies five 'archetype' personas used to describe different attitudes to domestic refurbishment, from which representative retrofit timelines were derived based on work the interviewees had undertaken on their homes. Then the process of using dynamic building simulation software (IES Virtual Environment) is described in relation to the impact of the derived retrofit timelines on a case study dwelling's annual and cumulative performance over a 25-year period. The results are reported, followed by a discussion of the implications these have for the development of future policy and conclusions based on the findings.

\section{Drivers for domestic retrofit}

In 2013 , domestic energy usage comprised $29 \%$ of the total energy used in the UK, with $66 \%$ of this used for space heating (DECC, 2014b). By making their home more energy efficient, the average household could save around two tonnes of $\mathrm{CO}_{2}$ per year (EST, 2006). As $\mathrm{CO}_{2}$ emissions can exist in the atmosphere for up to 200 years, efforts to realize these savings earlier will mitigate the extent of the challenge for future generations.

The energy efficiency of the UK housing stock has improved: between 1996 and 2010 the average rating according to the Standard Assessment Procedure (SAP) of UK homes increased by over 11 SAP points ${ }^{1}$ from 43.4 to 55.0 (Palmer \& Cooper, 2012). Government programmes (some now closed) that have contributed to this are summarized in Table 1.

Some homes are harder to treat than others, e.g. those with solid walls or no loft space, or in a general state of disrepair (EST, 2008, 2009) and often unable to make use of the standard measures. As a result, these homes require closer attention to refurbish them to acceptable standards and the Energy Company Obligation provides non-means-tested support for these more expensive measures under the Carbon Saving Obligation of the Green Deal (EST, 2013a). The extent of this challenge should not be underestimated because more than one-quarter of the English housing stock alone $(27 \%)$ is solid-wall construction (DCLG, 2013).

Whilst building regulations have progressively tightened since 1976 to make new dwellings more energy efficient, standards addressing existing construction have been slow to progress: maximum $U$-value standards for existing constructions may only apply if the homeowner is undertaking significant refurbishment work, and traditional buildings can often be subject to exception in cases where improvements are not cost-effective, or the building cannot accommodate typical retrofit technologies (HM Government, 2010).

Energy efficiency is often improved as a side-effect of home improvement, but it is thought to be rarely the main incentive for change. Earl and Peng (2011) go beyond just the physical aspects of home improvement to identify five reasons for motivating householders to make home improvements:

- to enhance the market value of the property or its potential rental yield

- to increase the property's marketability

- to enable the homeowner to meet new or existing lifestyle aspirations more cheaply than by selling up and buying an alternative property

- to enable the homeowner to enjoy enhanced social standing

- to meet psychological goals via the process of achieving the improvement

Clearly, energy efficiency alone does not drive the domestic refurbishment process, but a clearer understanding of how and when retrofit measures are installed will help identify where improvements to the process could be made.

Rather than a single major refurbishment addressing all issues in one process, it is much more usual for householders to retrofit their homes in a step-by-step approach over a number of years (Fawcett \& Mayne, 2012). This allows expense and disruption to be spread over time. Mallaband, Haines, and Mitchell (2012) report that homeowners 'save up' for improvements, or divide an improvement into stages to manage the cost, which also allows the work to be fitted in around other household events, such as holidays or perhaps the birth of a new baby. This provides particular opportunities for refurbishment, identified as trigger points (EST, 2011b), where there might be maximum potential for refurbishment at particular life stages of a household, including requiring space for growing children or preparing for retirement once older children have left home. However, Judson and 
Table 1 UK government schemes relating to residential properties to reduce the UK's $\mathrm{CO}_{2}$ emissions

Scheme Description

Community Energy Saving

Programme (CESP)

Carbon Emission Reduction Target (CERT)

Warm Front Scheme

Feed-InTariff (FIT)

Renewable Heat Premium Payment (RHPP)

Renewable Heat Incentive (RHI)

Green Deal

Energy Company Obligation (ECO)
Operating from 1 October 2009 to 31 December 2012, energy companies were obliged to achieve a 19.25 million tonne reduction in lifetime $\mathrm{CO}_{2}$ emissions through providing energy saving measures to the most deprived areas of the UK. The programme delivered a $16.31 \mathrm{Mt} \mathrm{CO}_{2}$ reduction, $84.7 \%$ of the target (Ofgem, 2013a)

Following on from the Energy Efficiency Commitment (EEC), CERToperated from 1 April 2008 to 31 December 2012. Energy companies exceeded the target of a $293 \mathrm{Mt}$ reduction in lifetime $\mathrm{CO}_{2}$ emissions for domestic customers (Ofgem 2013b)

Available from June 2000 to January 2013, this scheme targeted households in England most vulnerable to fuel poverty and living in the most inefficient dwellings. Grants to install insulation or a new heating system were available. Parallel programmes operated in Wales (Nest), Scotland (Energy Assistance Package) and Northern Ireland (Warm Homes Scheme) (Gov.UK, 2012)

Introduced in April 2010, energy suppliers pay a tariff to households for each kilowatt-hour of electricity generated via renewable or low carbon technologies, and any exported back to the grid. The tariff rates are typically available for 20 years after the installation date, though some technologies are less (e.g. Micro-CHP is 10 years). Solar photovoltaic (PV) offers higher tariff rates to homes able to demonstrate an Energy Performance Certificate (EPC) rating band D or better (EST, 2014a)

This scheme operated from August 2011 until the end of March 2014. Homeowners applied to the Energy Saving Trust (who were administrators of the scheme) to receive a single payment to assist with installing renewable heating technologies (e.g. ground-source heat pumps, air-source heat pumps, biomass boilers and solar systems). Preliminary figures at the end of the scheme indicated a total capacity of $132.7 \mathrm{MW}$ was installed under the householder scheme. The RHPP was superseded by the Renewable Heat Incentive (RHI) (DECC, 2014b)

Launched in April 2014, the domestic RHI rewards households for using renewable energy sources to heat their homes. The FIT, RHPP and RHI all form part of a wider government programme that aims to provide $15 \%$ of the UK's energy demand via renewable sources by 2020 (Gov.UK, 2014)

Launched in January 2013, the Green Deal programme allows homeowners to take out a loan to cover the cost of energy-efficiency improvements. The proposed work must meet the 'Golden Rule', which states that the energy savings realized over a 25-year period (or lifetime of the technology, if shorter) must be equal to or greater than the cost of implementation (i.e. the loan value plus interest) (Gov.UK, n.d.)

Introduced at the beginning of 2013 , the ECO was intended to replace the CERTand CESP schemes whilst working alongside the Green Deal. It places legal obligations on the larger energy suppliers. These are centred around three areas: Carbon Emissions Reduction Obligation (primarily focusing on hard-to-treat properties); Community Obligation (focusing on areas with low income); and Home Heating Cost Reduction Obligation (focusing on low-income and vulnerable households) (Ofgem, n.d.)
Maller (2014) recognize that other, wider, factors affect the refurbishment of a home. People often undertake home improvements at a time that suits the rest of their life, perhaps fitting in with events, the availability of money to finance the work or just to fit with their personal capacity to undertake the job (Mallaband et al., 2012). As a result, it is possible that the savings achieved by the work are less than the best possible. In her exploration of the time dimension of domestic retrofit, Fawcett (2014) identifies this issue as an unmet research need.

In revisions to the building regulations, the concept of 'consequential energy efficiency improvements' for work done on existing dwellings has been proposed. These would require homeowners to undertake additional efficiency measures when carrying out work elsewhere in the home, but have proved controversial, and currently they only apply to dwellings with floor areas greater than $1000 \mathrm{~m}^{2}$ (HM Government, 2010). Despite Uttlesford District Council demonstrating large-scale $\mathrm{CO}_{2}$ reductions through the implementation of consequential improvements (Building.co.uk, 2013) and evidence of householders' willingness to pay for associated energy saving work (EST, 2011b), the proposed changes to consequential improvements have been removed from the latest revision of the building regulations.

Previous work using notional intervention sequences (Banfill, Simpson, Loveday, \& Vadodaria, 2013b; Simpson \& Banfill, 2012) indicates that the improvement in operational performance achieved by a retrofit measure is not independent of the other measures in 
place. Whilst the previous work (seven retrofit measures applied in different sequences at three-year regular intervals) is of limited applicability to realworld retrofit scenarios, the findings demonstrate that the magnitude of energy savings realized by a given measure has the potential to vary in relation to its position within the retrofit sequence. The implications of this could be significant for schemes like the UK government's Green Deal (where a loan administered to install energy-efficiency measures is repaid through savings in the energy bill; DECC, 2013c) and warrants further investigation to optimize the design of future policy. Despite efforts to eliminate the financial barrier to energy-led refurbishment, figures for the Green Deal indicate a low uptake; the transition from previous schemes (which offered free or subsidized efficiency measures) has demonstrated a significant drop in installations, by as much as $97 \%$ in the case of cavity wall insulation (Pitt, 2013). ${ }^{2}$

\section{Homeowner interviews Participants}

Interviews were conducted with the occupants from 20 households from the East Midlands region of the UK. All households lived in owner-occupied solid-wall houses and participants were selected using a purposive sampling approach so that they represented a wide range of family structures, incomes and social statuses, house and household types (Mallaband et al., 2012). Data from the 2006 English House Condition Survey (EHCS) were statistically analysed to derive a representative spread of solid-wall dwelling types in England. From this, it was concluded that a 'representative' sample of solid-wall dwellings in England would be comprised of houses that were end-ofterrace, mid-terrace, semi-detached and detached properties, occupied by owners and private tenants, with household size predominately in the range of one to four, having an even mix of household composition (ranging from singles, couples with and without children, and elderly singles and couples) and having mains gas heating. The CALEBRE project ${ }^{3}$ was only focusing on owner-occupiers, so no private tenants were recruited. Although never intended to be statistically representative of the population, as this was a rich qualitative study with a small sample size, the approach allowed a snapshot of different domestic situations to be explored, using a maximum variation sample (Marshall, 1996) within the boundaries of typical solid-wall dwellings in England. The current study formed part of a wider programme of work within the CALEBRE project (Vadodaria et al., 2010).

The aim of each interview was to discover the underlying factors for previous home improvements undertaken by the participants, by focusing on the motivations, barriers and enablers associated with the improvements.
A timeline exercise was designed to uncover the different home improvements that were conducted in the house (Haines, Mitchell, \& Mallaband, 2010; Mallaband et al., 2013). Householders were encouraged to be frank and open when discussing the changes and improvements they had made to their home. They were asked to give the rationale for purchasing the property and to discuss the changes that have been performed from the point of purchase onwards.

Although the interview was designed within an energy project, energy-efficiency measures were not the specific focus of the discussion, as the researchers wanted to consider wider issues affecting retrofit. However, many home improvements bring with them energy savings, e.g. a new boiler or heating system improves efficiency of delivery of heat to a house; the replacement of single-glazed windows with doubleglazing improves their $U$-value; the installation of a fitted carpet reduces draughts. Discussions identified when each improvement was undertaken (usually to the nearest year) and, with the help of the householders, these were mapped onto a timeline. Householders often recollected home improvements in relation to other personal events, such as children moving schools, a birth or death in the family, insurance claims etc. and so were able to recall the dates and events easily. Where further accuracy was needed, some householders referred to paperwork collected at the time of the refurbishment, increasing the validity of the information provided.

\section{Personas}

Results from the interviews and timelines were analysed, identifying the type and date of each improvement for each household. A further, detailed analysis of the interview data was undertaken, and five personas were created (Haines \& Mitchell, 2014), following a method from Goodwin (2010). Personas represent archetypal people and are widely used within user experience design to support the design of digital products and services (e.g. McKay, 2013; Mulder \& Yaar, 2006). Personas are designed to support design decision-making by structuring the variance within a target market relevant to the project focus and to create rich holistic representations of people that can be used to build shared understanding between different disciplines. The personas in this study were created primarily to describe the archetypal approaches to home improvement that emerged from the research with a view to understanding opportunities for future renovation:

- Persona A: 'Idealist restorers' - householders who spend time restoring their home through structural and cosmetic improvement, aiming to create a house that included many of its original features. 
- Persona B: 'Aesthetic Pragmatists' - householders who want to create a home that meets their practical needs as well as being full of character and charm.

- Persona C: 'Functional Pragmatists' - householders who want a home that allows a full and active life but are not particularly interested in keeping older features of their house.

- Persona D: 'Service Seekers' - householders who have reached a point in their life where they can afford to pay for a better service. They view their house as a substantial financial asset and want to ensure any improvements to it add value and quality to their home.

- Persona E: 'Property Ladder Climbers' - householders who buy and renovate a house to sell on, putting considerable time and effort into their home in a short space of time, allowing them to move up the property ladder more quickly.

These personas do not represent the entire spectrum of home improvers, nor do they represent any one particular person, but draw attention to the different types of home improvers.

\section{Example persona households}

From the interview process, one household was selected for each of the five personas that best represented the characteristics of that persona. All these households had resided at their property for an extended period of time and/or had made a suitable number of energy-saving improvements to their homes.

Table 2 shows the work actually undertaken by each 'example persona' household in their dwelling (Persona $\mathrm{A}=$ Dwelling $\mathrm{A}$ ), with year zero indicating any work undertaken prior to moving in. Table 3 summarizes this information in a timeline. None of the households installed every retrofit technology considered in this paper, but it was possible to identify opportunities where the measures could have been installed alongside other work undertaken, such as redecoration, with minimal additional disruption. Efficiency improvements installed as part of the work actually undertaken on the property are indicated in plain text, and 'potential opportunities' for additional efficiency improvements (or efforts where measures were only partially installed) are signalled with italic text.

The most popular measures installed were the most straightforward: draughtproofing, loft insulation or, where a professional was involved, installation of a more efficient boiler and improved glazing. Wall and ground insulation, measures which pose considerable disruption for the occupants, were only undertaken in three of the five households, and in these instances often only partially installed (e.g. along one wall, or within a limited number of rooms). These timelines were used as the basis for the improvements applied to the case study house for the simulation of the energy consumption.

\section{Retrofit sequence \\ Concept and overview}

The concept behind the investigation of the effect of the retrofit sequence on energy use is shown schematically in Figure 1. If no improvements are carried out, the baseline annual rate of energy use can be represented by the horizontal line XY. A house may be refurbished as a single package of retrofit measures, i.e. a whole-house retrofit (scenario A), in which case the annual rate drops in a single step from the unimproved to the improved building (line WZ). The total energy savings over $n$ years are then given by the area (WXYZ) between the two lines.

For the reasons discussed above, supported by the wider literature and the case study examples described in Table 2, the interventions may be spread over a number of years (scenario B), with the rate dropping in a series of steps following application of each measure. In this case the total energy savings over $n$ years are less, reflected by the smaller area between the baseline (XY) and the reduction profile (XZ).

If each individual measure (M1, ., M6) has an effect on the energy use that is independent both of the others and of the order in which they are carried out, the annual rate of energy use after everything has been done is the same as in scenario A (point Z1), giving the reduction profile labelled $\mathrm{B}(\mathrm{a})$. If they are not independent then both the reduction profile and the final annual energy use is different, as shown by $\mathrm{B}(\mathrm{b})$, leading to point Z2. The total energy savings over $n$ years are also different because of the different areas (XYZ1 and XYZ2) on the respective profiles. As the energy consumptions in the scenarios $(\mathrm{A}, \mathrm{B}(\mathrm{a})$ and $\mathrm{B}(\mathrm{b}))$ are different, the total carbon emissions and operating costs over the $n$-year period will be different. Therefore this work aimed to explore the impact of the retrofit intervention sequence on the energy consumption and $\mathrm{CO}_{2}$ emissions, associated with operating a case study dwelling.

\section{Case study dwelling}

Retrofit measures were applied in simulations of the E.ON Retrofit Test House, located on the campus of the University of Nottingham, UK. This two-storey, semi-detached dwelling has three bedrooms, and a total internal floor area of $99.5 \mathrm{~m}^{2}$ (see Figure 2 and the corresponding simulation model in Figure 3). It was constructed in 2008, but built according to 1930s' standards, in order to demonstrate the effects 
Table 2 Work undertaken by interview participants identified for the 'example personas'

\begin{tabular}{|c|c|c|c|c|}
\hline $\begin{array}{l}\text { Example } \\
\text { archetype }\end{array}$ & $\begin{array}{l}\text { Improvement } \\
\text { stage }\end{array}$ & Year & Work undertaken & $\begin{array}{l}\text { Efficiency improvement identified } \\
\text { for theoretical retrofit sequence }\end{array}$ \\
\hline \multirow[t]{3}{*}{ Restorers } & (i) & 0 & $\begin{array}{l}\text { Upon moving in, the occupants 'turned the house into a } \\
\text { building site.'This was predominantly for functional and } \\
\text { aesthetic reasons, rather than any efficiency benefit, } \\
\text { but did involve the replacement of the existing single- } \\
\text { glazing }\end{array}$ & $\begin{array}{l}\text { Replacement double-glazing } \\
\text { throughout the property }\end{array}$ \\
\hline & (ii) & 1 & $\begin{array}{l}\text { A new boiler and central heating system were installed } \\
\text { within the first year where previously there was none }\end{array}$ & New condensing boiler \\
\hline & (iii) & 5 & $\begin{array}{l}\text { Draughtproofing was undertaken to address an } \\
\text { 'absolutely freezing room', and a loft conversion } \\
\text { improved the thermal properties of the external } \\
\text { envelope. }\end{array}$ & Draughtproofing and loft insulation \\
\hline \multirow[t]{4}{*}{$\begin{array}{l}\text { Aesthetic } \\
\quad \text { Pragmatists }\end{array}$} & (i) & 3 & $\begin{array}{l}\text { The occupants were notable for taking action to address } \\
\text { identified problems, but this was not necessarily driven } \\
\text { by a desire to conserve energy. Draughtproofing work } \\
\text { was undertaken to improve comfort, and insulation was } \\
\text { applied to internal wall surfaces to address } \\
\text { condensation problems }\end{array}$ & Wall insulation and draughtproofing \\
\hline & (ii) & 5 & $\begin{array}{l}\text { Floor insulation was installed to prevent cold air rising } \\
\text { through the floor boards from the cellar }\end{array}$ & Ground insulation \\
\hline & (iii) & 7 & $\begin{array}{l}\text { An attic conversion improved the thermal properties } \\
\text { associated with the roof, but also required the boiler to } \\
\text { be replaced due to the increased heating requirement. }\end{array}$ & $\begin{array}{l}\text { Loft insulation and new condensing } \\
\text { boiler }\end{array}$ \\
\hline & (iv) & 19 & $\begin{array}{l}\text { Efforts to replace glazing were motivated by a desire to } \\
\text { reduce draughts, as well as noise and heating bills. The } \\
\text { occupants were prepared to pay more to install glazing } \\
\text { that would maintain the aesthetics of the older dwelling }\end{array}$ & $\begin{array}{l}\text { Replacement double-glazing } \\
\text { throughout the property }\end{array}$ \\
\hline \multirow{6}{*}{$\begin{array}{l}\text { Functional } \\
\text { Pragmatists }\end{array}$} & (i) & 2 & Grant funding enabled them to carry out work on the roof & Loft insulation \\
\hline & (ii) & 7 & $\begin{array}{l}\text { It was intended that the elderly mother of one of the } \\
\text { occupants would move into the upper level of the } \\
\text { dwelling, therefore she provided funding to upgrade half } \\
\text { of the windows to double-glazing }\end{array}$ & $\begin{array}{l}\text { Replacement double-glazing to the } \\
\text { front of the property }\end{array}$ \\
\hline & (iii) & 10 & $\begin{array}{l}\text { Efforts were made to address problems as they were } \\
\text { identified, and as were practical for the family, such as } \\
\text { capping chimneys to eliminate draughts }\end{array}$ & Draughtproofing \\
\hline & (iv) & 12 & $\begin{array}{l}\text { Occupants upgraded the remaining single- to double- } \\
\text { glazing }\end{array}$ & $\begin{array}{l}\text { Replacement double-glazing to rear } \\
\text { windows }\end{array}$ \\
\hline & (v) & 13 & $\begin{array}{l}\text { The kitchen floor was redone, and this subsequently } \\
\text { resulted in work on other areas of the flooring where } \\
\text { rotten wood was discovered under the carpets }\end{array}$ & Ground insulation \\
\hline & (vi) & 20 & $\begin{array}{l}\text { The occupants were responsive to advice from } \\
\text { government and environmental agencies. They } \\
\text { installed a more efficient condensing boiler, but noted } \\
\text { that the reduction in their energy bill was not as } \\
\text { substantial as they had expected, based on the } \\
\text { information they were provided. Insulation was applied } \\
\text { to the external walls of just the bathroom and utility } \\
\text { room where the occupants noted these were } \\
\text { particularly cold spaces }\end{array}$ & $\begin{array}{l}\text { Wall insulation and new condensing } \\
\text { boiler }\end{array}$ \\
\hline \multirow[t]{5}{*}{$\begin{array}{l}\text { Service } \\
\quad \text { Seekers }\end{array}$} & (i) & 0 & $\begin{array}{l}\text { The occupants continued to rent while initial } \\
\text { improvements were carried out on their home, } \\
\text { including the installation of loft insulation and } \\
\text { replacement of the existing glazing }\end{array}$ & $\begin{array}{l}\text { Loft insulation and replacement } \\
\text { double-glazing throughout the } \\
\text { property }\end{array}$ \\
\hline & (ii) & 1 & $\begin{array}{l}\text { Within a year of moving in the occupants were also able to } \\
\text { fund the replacement of the existing boiler with a more } \\
\text { efficient model }\end{array}$ & New condensing boiler \\
\hline & (iii) & 2 & $\begin{array}{l}\text { Subsequent work was predominantly aesthetic, until a } \\
\text { porch was constructed to help eliminate a significant } \\
\text { draught problem }\end{array}$ & Draughtproofing \\
\hline & (iv) & 4 & $\begin{array}{l}\text { A number of rooms were converted, which involved } \\
\text { improving the thermal properties of the external walls }\end{array}$ & Wall insulation \\
\hline & (v) & 21 & $\begin{array}{l}\text { The kitchen floor was redone, and under-floor heating } \\
\text { installed }\end{array}$ & Ground insulation \\
\hline
\end{tabular}


Table 2 Continued

\begin{tabular}{|c|c|c|c|c|}
\hline $\begin{array}{l}\text { Example } \\
\text { archetype }\end{array}$ & $\begin{array}{l}\text { Improvement } \\
\text { stage }\end{array}$ & Year & Work undertaken & $\begin{array}{l}\text { Efficiency improvement identified } \\
\text { for theoretical retrofit sequence }\end{array}$ \\
\hline \multirow[t]{3}{*}{$\begin{array}{l}\text { Property Ladder } \\
\text { Climbers }\end{array}$} & (i) & 0 & $\begin{array}{l}\text { The occupants had previously renovated and sold a house } \\
\text { for profit, and were looking to do the same with their } \\
\text { new home. Condemnation of the existing boiler } \\
\text { necessitated them to address this over anything else }\end{array}$ & New condensing boiler \\
\hline & (ii) & 1 & $\begin{array}{l}\text { Subsequent work was predominantly aesthetic, but } \\
\text { included the installation of new laminate flooring } \\
\text { throughout }\end{array}$ & Ground insulation \\
\hline & (iii) & 3 & $\begin{array}{l}\text { The occupants identified that the arrival of their baby } \\
\text { slowed the progression of the renovation project, } \\
\text { however by the third year of occupying their home they } \\
\text { had installed loft insulation, replaced the existing } \\
\text { glazing and draughtproofed problem areas. As the baby } \\
\text { became more mobile, work on the property ceased }\end{array}$ & $\begin{array}{l}\text { Loft insulation, replacement double- } \\
\text { glazing throughout and } \\
\text { draughtproofing }\end{array}$ \\
\hline
\end{tabular}

Table 3 Summary timeline of retrofit measures

\begin{tabular}{|c|c|c|c|c|c|}
\hline \multirow[t]{2}{*}{ Year } & \multicolumn{5}{|c|}{ Dwelling simulation } \\
\hline & A: Restorers & $\begin{array}{l}\text { B: Aesthetic } \\
\text { Pragmatists }\end{array}$ & C: Functional Pragmatists & D: Service Seekers & $\begin{array}{l}\text { E: Property Ladder } \\
\text { Climbers }\end{array}$ \\
\hline 0 & $\begin{array}{l}\text { (i) Replacement } \\
\text { double-glazing } \\
\text { throughout the } \\
\text { property }\end{array}$ & & & $\begin{array}{l}\text { (i) Loft insulation and } \\
\text { replacement } \\
\text { double-glazing } \\
\text { throughout }\end{array}$ & (i) New condensing boiler \\
\hline 1 & $\begin{array}{l}\text { (ii) New condensing } \\
\text { boiler }\end{array}$ & & & $\begin{array}{l}\text { (ii) New condensing } \\
\text { boiler }\end{array}$ & $\begin{array}{l}\text { (ii) Ground floor } \\
\text { insulation }\end{array}$ \\
\hline 2 & & & (i) Loft insulation & (iii) Draughtproofing & \\
\hline 3 & & $\begin{array}{l}\text { (i) Wall insulation and } \\
\text { draughtproofing }\end{array}$ & & & $\begin{array}{l}\text { (iii) Loft insulation, } \\
\text { replacement double- } \\
\text { glazing throughout } \\
\text { and draughtproofing }\end{array}$ \\
\hline 4 & & & & (iv) Wall insulation & \\
\hline 5 & $\begin{array}{l}\text { (iii) Draughtproofing } \\
\text { and loft insulation }\end{array}$ & $\begin{array}{l}\text { (ii) Ground floor } \\
\text { insulation }\end{array}$ & & & \\
\hline $6-10$ & & $\begin{array}{l}\text { (iii) Loft insulation and } \\
\text { new condensing } \\
\text { boiler (year 7) }\end{array}$ & $\begin{array}{l}\text { (ii) Replacement double- } \\
\text { glazing to half the } \\
\text { windows (year } 7 \text { ) } \\
\text { (iii) Draughtproofing (year 10) }\end{array}$ & & \\
\hline $11-15$ & & & $\begin{array}{l}\text { (iv) Replacement double- } \\
\text { glazing to the remaining } \\
\text { half of the windows (year } \\
12 \text { ) } \\
\text { (v) Ground floor insulation } \\
\text { (year 13) }\end{array}$ & & \\
\hline $16-20$ & & $\begin{array}{l}\text { (iv) Replacement } \\
\text { double-glazing } \\
\text { throughout the } \\
\text { property (year 19) }\end{array}$ & $\begin{array}{l}\text { (vi) Wall insulation and new } \\
\text { condensing boiler (year } \\
20 \text { ) }\end{array}$ & & \\
\hline $21-25$ & & & & $\begin{array}{l}\text { (v) Ground floor } \\
\text { insulation (year 21) }\end{array}$ & \\
\hline
\end{tabular}

of installing retrofit technologies in an existing dwelling. The focus on an older dwelling (that specifically presents many additional challenges to implementing efficiency measures) is based on the recognition that they represent a significant proportion of the domestic building stock. From a total of 22.8 million homes in 


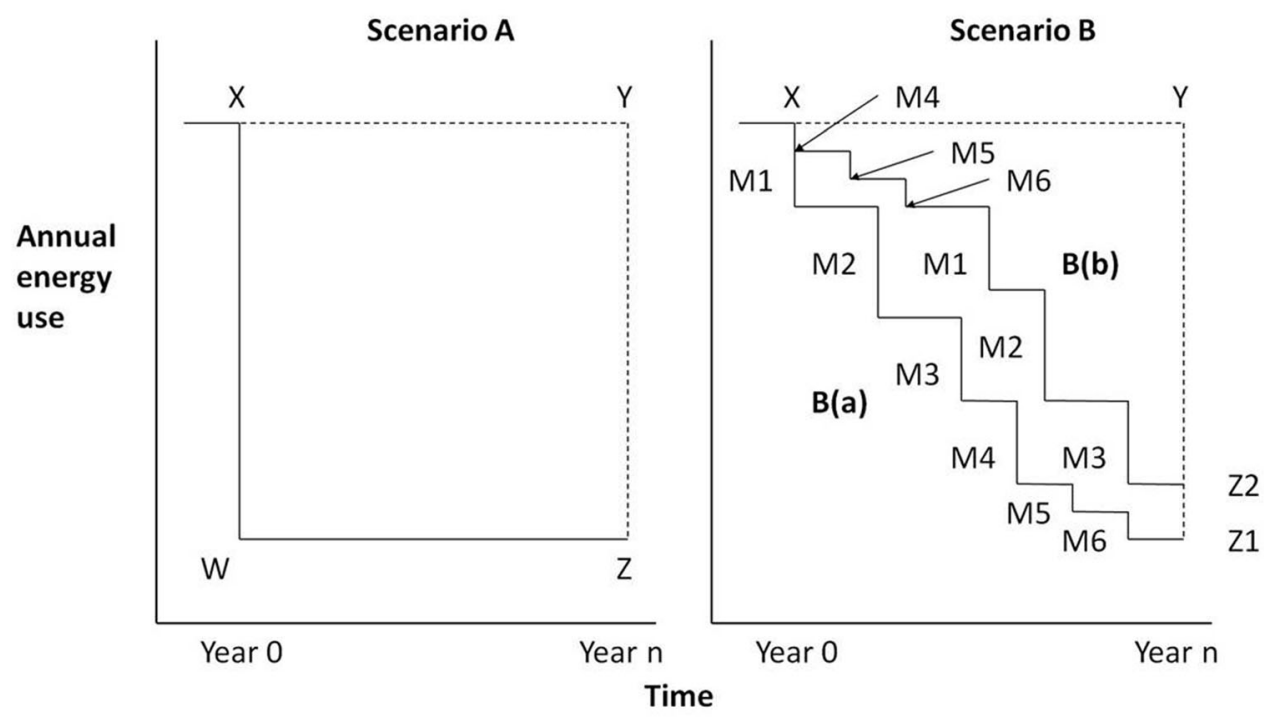

Figure 1 Reductions in annual energy use resulting from a complete package of retrofit measures (Scenario $A$ ) and from retrofit carried out in stages (Scenarios $\mathrm{B}(\mathrm{a})$ and $\mathrm{B}(\mathrm{b})$ )

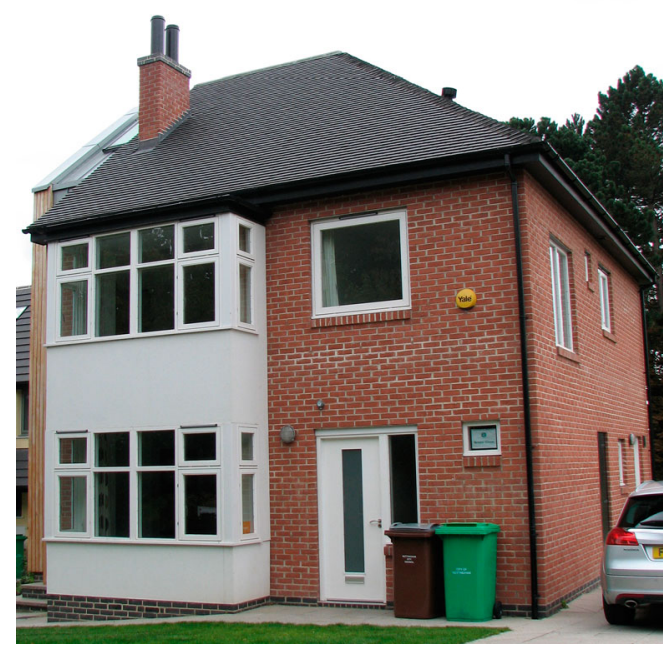

Figure 2 E.ON retrofit test house, University of Nottingham

England, almost $40 \%$ were constructed before 1945 and solid-wall dwellings account for $27 \%$ of the total stock (DCLG, 2013).

The E.ON Retrofit Test House shares many characteristics with the older properties occupied by the interview participants (see the example in Figure 4), in terms of size, construction details and building services strategies. Therefore it was considered appropriate for use as a case study in this investigation.

Table 4 summarizes the building performance specifications associated with the systems in the E.ON

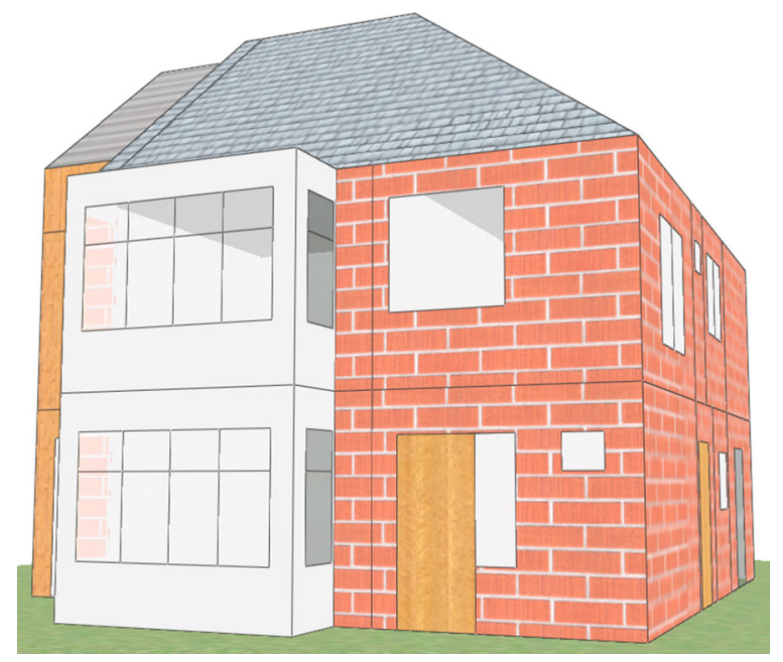

Figure 3 IES Virtual Environment dynamic Thermal model of the E.ON retrofit test house

Retrofit Test House for both its original 'baseline' and modified states post-retrofit. The technologies selected were based on those installed in the E.ON Retrofit Test House (Gillott, Loveday, \& Vadodaria, 2013). This comprises a range of products readily available on the market, but does not represent an exhaustive list of the technologies available to achieve energy and $\mathrm{CO}_{2}$ emission reductions. The post-retrofit performance parameters are specified to meet compliance with the minimum building standards applicable at the time of installation (HM Government, 2010). 


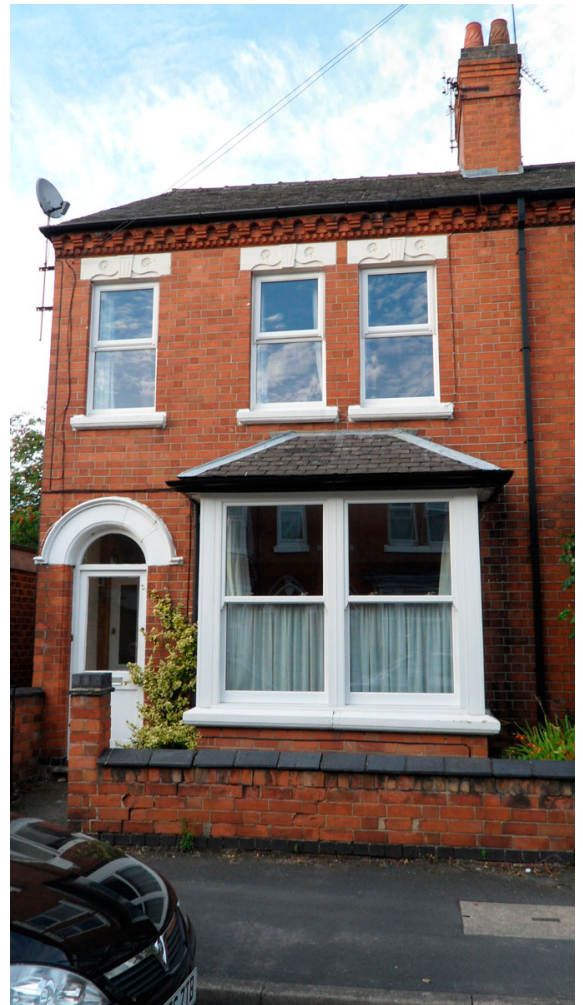

Figure 4 A home typical of the interview sample

\section{Simulation model}

Dynamic thermal modelling software IES Virtual Environment (version 6.3.0.1) (IES, n.d.) was used to simulate a year's operation of the E.ON Retrofit Test House in its original baseline state, in order to determine the annual energy consumption and $\mathrm{CO}_{2}$ emissions. This was achieved using a number of modules: ModelIt, to construct a multi-zone model; Apache, to describe the operational characteristics for each zone (such as heating set points and internal gains) and create the construction properties; heating, ventilation and air-conditioning (HVAC) to detail the heating and mechanical ventilation strategies; and Macroflo to simulate a natural ventilation strategy. The parameters associated with individual room templates have been used previously (Gillott et al., 2013; Simpson \& Banfill, 2012). The Nottingham Chartered Institution of Building Services Engineers (CIBSE) TRY weather file was used to simulate 'typical' weather conditions for the case study location in all the simulations.

The timeline of work derived from each example persona was used to produce retrofit sequences that could be input into the model (Table 5). Annual energy consumption and cumulative $\mathrm{CO}_{2}$ emissions over a 25 -year period were determined. The carbon intensities detailed in SAP for natural gas and grid electricity (BRE, 2009) were used to convert the energy data into $\mathrm{CO}_{2}$ emissions. The cumulative emissions associated with the baseline E.ON Retrofit Test House, subject to no improvements, were also calculated, in addition to simulating a whole-house retrofit strategy (i.e. applying all retrofit measures detailed in Table 4, including mechanical ventilation with heat recovery (MVHR) and additional draughtproofing) undertaken at the start of the process.

Whilst some of the improvement efforts applied by the example personas involved only the partial application

Table 4 Summary of performance parameters representing the E.ON Retrofit Test House before and after the application of retrofit measures

\begin{tabular}{|c|c|c|}
\hline & Baseline & Post-retrofit \\
\hline Boiler & Non-condensing boiler, $80 \%$ efficient & Modern condensing boiler, $90.2 \%$ efficient \\
\hline External Walls & Solid brick construction, $U$-value $=1.7 \mathrm{~W} / \mathrm{m}^{2} . \mathrm{K}$ & $\begin{array}{l}\text { Solid brick construction with external insulation, } U \text {-value }= \\
0.3 \mathrm{~W} / \mathrm{m}^{2} . \mathrm{K}\end{array}$ \\
\hline Roof & Unheated loft space, slate tiles with no insulation & $\begin{array}{l}\text { Unheated loft space, slate tiles with } 270 \mathrm{~mm} \text { insulation to } \\
U \text {-value }=0.16 \mathrm{~W} / \mathrm{m}^{2} . \mathrm{K}\end{array}$ \\
\hline Ground Floor & Suspended timber flooring, $U$-value $=0.6 \mathrm{~W} / \mathrm{m}^{2} . \mathrm{K}$ & $\begin{array}{l}\text { Suspended timber flooring with insulation, } U \text {-value }=0.2 \mathrm{~W} / \\
\mathrm{m}^{2} . \mathrm{K}\end{array}$ \\
\hline Glazing & $\begin{array}{l}\text { Single-glazing with wooden frames, } U \text {-value }=5.5 \mathrm{~W} / \\
\mathrm{m}^{2} . \mathrm{K}, g \text {-value }=0.82\end{array}$ & $\begin{array}{l}\text { Double-glazing with wooden frames, } U \text {-value }=1.8 \mathrm{~W} / \mathrm{m}^{2} . \mathrm{K} \\
g \text {-value }=0.64\end{array}$ \\
\hline Air tightness & $15 \mathrm{~m}^{3} / \mathrm{m}^{2} . \mathrm{h}$ at $50 \mathrm{~Pa}$ & $\begin{array}{l}\text { Stage } 1 \text { draughtproofing to } 10 \mathrm{~m}^{3} / \mathrm{m}^{2} \text {.h at } 50 \mathrm{~Pa} \\
\text { Stage } 2 \text { draughtproofing to } 5 \mathrm{~m}^{3} / \mathrm{m}^{2} . h \text { at } 50 \mathrm{~Pa}\end{array}$ \\
\hline $\begin{array}{l}\text { Ventilation } \\
\text { strategy }\end{array}$ & $\begin{array}{l}\text { Natural ventilation with intermittent extract, SFP }= \\
0.5 \mathrm{~W} / \mathrm{l} / \mathrm{s}\end{array}$ & $\begin{array}{l}\text { Natural ventilation with intermittent extract, SFP }=0.5 \mathrm{~W} / \mathrm{I} / \mathrm{s} \\
\text { Where MVHR is installed: SFP }=1.2 \mathrm{~W} / \mathrm{l} / \mathrm{s} \text {, heat recovery } \\
\text { efficiency }=80 \%\end{array}$ \\
\hline
\end{tabular}

Note: SFP $=$ specific fan power demand on an air distribution system 
Table 5 Timeline and order of installation of retrofit measures

\begin{tabular}{|c|c|c|c|c|c|}
\hline Household & \multicolumn{2}{|c|}{ Year } & Work undertaken & $\begin{array}{l}\text { Incremental energy } \\
\text { reduction (MWh/annum) }\end{array}$ & $\begin{array}{c}\text { Resulting annual energy } \\
\text { consumption (MWh/annum) }\end{array}$ \\
\hline $\begin{array}{l}\text { Baseline E.ON } \\
\text { Retrofit Test } \\
\text { House }\end{array}$ & \multicolumn{2}{|c|}{ n.a. } & n.a. & - & 44.11 \\
\hline \multirow[t]{3}{*}{ A: Restorers } & (i) & 0 & $\begin{array}{l}\text { Replacement double-glazing } \\
\text { throughout the property }\end{array}$ & 7.15 & 36.96 \\
\hline & (ii) & 1 & New condensing boiler & 3.74 & 33.21 \\
\hline & (iii) & 5 & Draughtproofing and loft insulation & 4.37 & 28.84 \\
\hline \multirow{4}{*}{$\begin{array}{l}\text { B: Aesthetic } \\
\text { Pragmatists }\end{array}$} & (i) & 3 & Wall insulation and draughtproofing & 7.42 & 36.68 \\
\hline & (ii) & 5 & Ground floor insulation & 1.49 & 35.19 \\
\hline & (iii) & 7 & $\begin{array}{l}\text { Loft insulation and new condensing } \\
\text { boiler }\end{array}$ & 7.65 & 27.55 \\
\hline & (iv) & 19 & $\begin{array}{l}\text { Replacement double-glazing } \\
\text { throughout the property }\end{array}$ & 8.19 & 19.36 \\
\hline \multirow{6}{*}{$\begin{array}{l}\text { C: Functional } \\
\text { Pragmatists }\end{array}$} & (i) & 2 & Loft insulation & 2.96 & 41.15 \\
\hline & (ii) & 7 & $\begin{array}{l}\text { Replacement double-glazing to half the } \\
\text { windows }\end{array}$ & 4.83 & 36.32 \\
\hline & (iii) & 10 & Draughtproofing & 1.54 & 34.78 \\
\hline & (iv) & 12 & $\begin{array}{l}\text { Replacement double-glazing to the } \\
\text { remaining half of the windows }\end{array}$ & 2.74 & 32.04 \\
\hline & $(v)$ & 13 & Ground floor insulation & 1.54 & 30.50 \\
\hline & (vi) & 20 & $\begin{array}{l}\text { Wall insulation and new condensing } \\
\text { boiler }\end{array}$ & 11.13 & 19.36 \\
\hline \multirow[t]{5}{*}{ D: Service Seekers } & (i) & 0 & $\begin{array}{l}\text { Loft insulation and replacement double- } \\
\text { glazing throughout }\end{array}$ & 10.45 & 33.65 \\
\hline & (ii) & 1 & New condensing boiler & 4.58 & 29.08 \\
\hline & (iii) & 2 & Draughtproofing & 1.44 & 27.64 \\
\hline & (iv) & 4 & Wall insulation & 6.63 & 21.00 \\
\hline & (v) & 21 & Ground floor insulation & 1.64 & 19.36 \\
\hline \multirow{3}{*}{$\begin{array}{l}\text { E: Property Ladder } \\
\text { Climbers }\end{array}$} & (i) & 0 & New condensing boiler & 3.93 & 40.18 \\
\hline & (ii) & 1 & Ground floor insulation & 1.09 & 39.08 \\
\hline & (iii) & 3 & $\begin{array}{l}\text { Loft insulation, replacement double- } \\
\text { glazing throughout and } \\
\text { draughtproofing }\end{array}$ & 11.26 & 27.82 \\
\hline Whole-house retrofit & (i) & 0 & $\begin{array}{l}\text { Application of all measures detailed in } \\
\text { Table } 3\end{array}$ & 27.37 & 16.73 \\
\hline
\end{tabular}

of some measures (e.g. wall insulation may have been installed in only a limited number of rooms as they were being redecorated), the simulations consider the complete application of the specified retrofit measure, unless otherwise stated.

No opportunities to install MVHR and further draughtproof the dwelling to achieve the required low air permeability (Banfill, Simpson, Loveday, \& Vadodaria, 2013a) were identified for any of the sequences considered.

As a number of assumptions, consistent throughout the simulations, have been made regarding occupant behaviour, the values reported in this paper represent 'theoretical' scenarios. This allows the effect of changes to the retrofit sequence to be investigated and compared for the case study dwelling. The data reported can in no way be considered representative of the energy consumption associated either with the actual E.ON Retrofit Test House, or the homes of the example personas. It should also be noted that this study applies a dynamic simulation and outputs will differ to those generated by the Reduced Data Standard Assessment Procedure (required by UK government to produce an Energy Performance Certificate (EPC) for existing dwellings) which uses a simplified, steady-state calculation.

\section{Results}

This section describes the simulation results for energy consumption and $\mathrm{CO}_{2}$ emissions. Table 5 shows the annual energy consumption for each stage in the five 'theoretical' retrofit sequences compared with the 'baseline' and 'whole-house retrofit' energy consumption. 
The incremental energy reduction values show the effect of the retrofit measure compared with the preceding stage and the annual energy consumption prior to stage (i) is that of the baseline dwelling.

\section{Annual energy consumption}

Table 5 shows that replacing single- by doubleglazing and installing wall insulation has the biggest effect on energy consumption, whilst ground floor insulation and draughtproofing deliver the smallest savings. By the end of 25 years, dwellings B (Aesthetic Pragmatists), C (Functional Pragmatists) and D (Service Seekers) have all received the same retrofit technologies, albeit in different sequence and to different timescales. As a result, the final annual energy consumption for these three dwellings is identical, a $56 \%$ reduction from the baseline dwelling. Dwellings A (Idealist restorers) and E (Property Ladder Climbers), on the other hand, do not feature wall insulation, and the former also lacks ground floor insulation. As a result the annual energy consumption for both dwellings is about $35 \%$ less than the baseline dwelling.

None of the dwellings features stage 2 draughtproofing (to an air permeability of $5 \mathrm{~m}^{3} / \mathrm{m}^{2} . h$ at $50 \mathrm{~Pa}$ ) or installation of an MVHR system, because there were no opportunities to include these measures within the proposed sequences. These are, however, included as part of the whole-house retrofit, and contribute to an overall $62 \%$ reduction in annual energy consumption relative to the baseline dwelling, an additional $6 \%$ on the savings realized by dwellings $\mathrm{B}-\mathrm{D}$.

\section{Cumulative energy and $\mathrm{CO}_{2}$ emission reductions}

Following the style of Figure 1, Figure 5 shows the annual energy consumption, as reported in Table 5, over a 25-year period (starting from a pre-retrofit state) for the simulations representing the five retrofit scenarios, the baseline dwelling and the whole-house retrofit. Each step change corresponds to the reduction in annual energy consumption associated with the retrofit measures implemented in that year. Where the graph plots energy consumption against time, the volume occupied by each coloured segment is indicative of the cumulative energy consumption over the 25 -year period.

Incidentally, whilst the order of presentation in Figure 5 was selected for visual clarity, this corresponds with the order of increasing cumulative $\mathrm{CO}_{2}$ emissions which are shown in Figure 6. Both figures provide a framework for further discussion.

\section{Highest cumulative emissions}

Dwelling C (Functional Pragmatists) has the highest cumulative $\mathrm{CO}_{2}$ emissions, despite being one of the dwellings to realize the lowest annual emissions by the end of the 25-year period. In this case, the occupants undertook work on their home as they encountered problems, rather than taking a preventative approach. This contributes to the widely dispersed

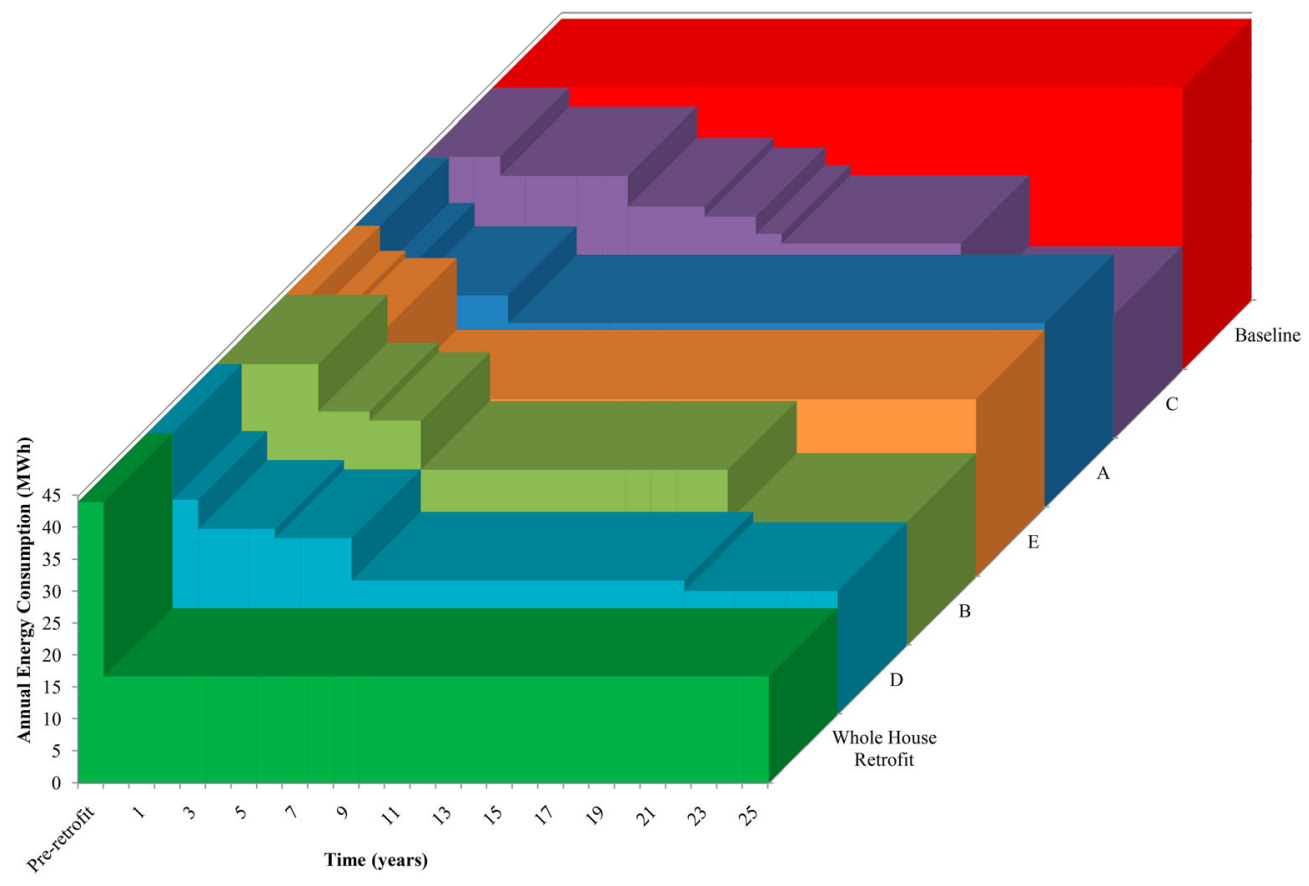

Figure 5 Baseline and retrofitted properties: annual energy consumption over a 25-year period 


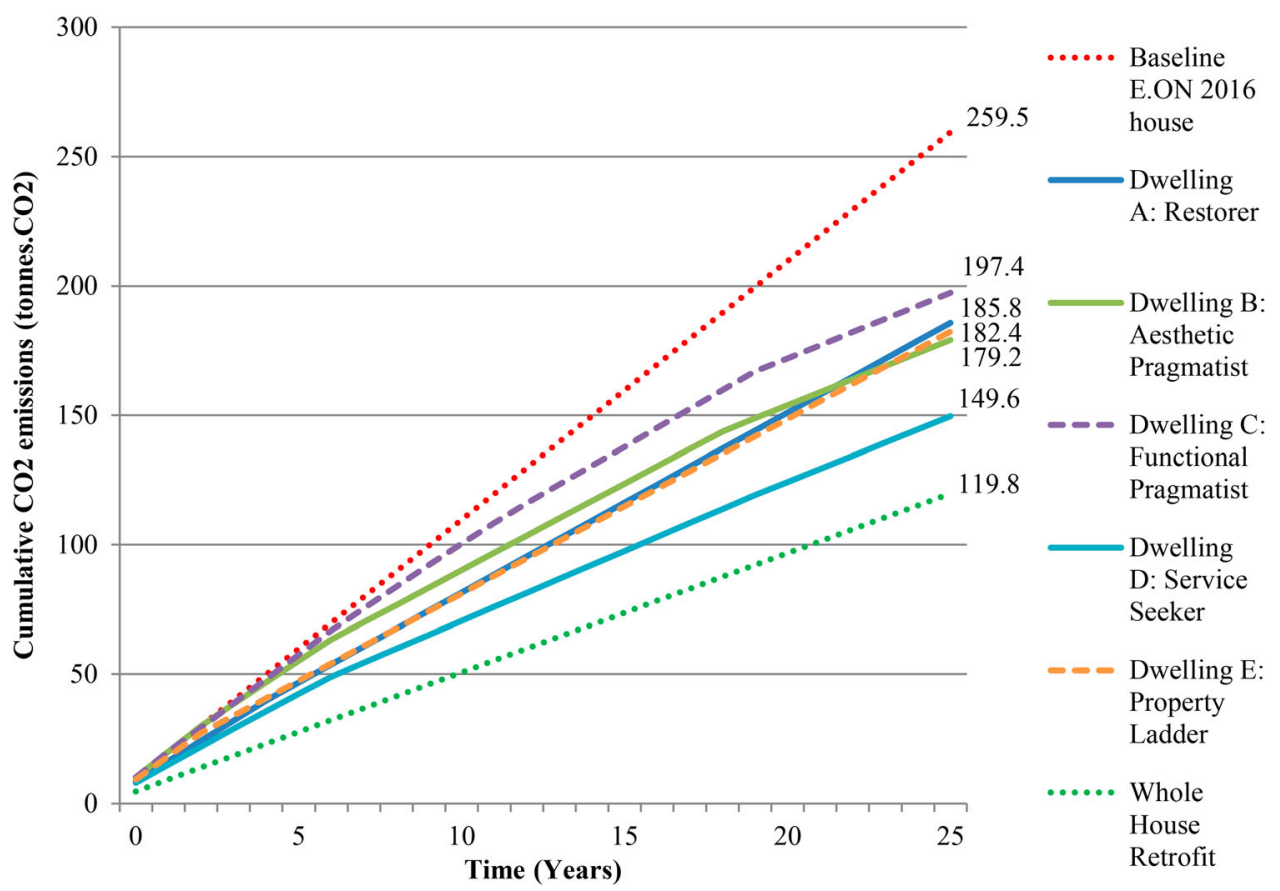

Figure 6 Baseline and retrofitted properties: cumulative $\mathrm{CO}_{2}$ emissions

measures, installed in six stages between years 2 and 20. As a result dwelling $\mathrm{C}$ shows the least reduction in cumulative $\mathrm{CO}_{2}$ emissions $(24 \%)$ relative to the baseline dwelling.

\section{Lowest cumulative emissions}

In contrast, the Service Seekers (dwelling D) have reached a point in their life where they can afford to invest in their homes. This is reflected by the simulated archetype, which commences retrofit before moving in and installs the majority of measures (including relatively expensive double-glazing and wall insulation) by year 4. Dwelling D shows the lowest cumulative $\mathrm{CO}_{2}$ emissions, $42 \%$ below the baseline dwelling by the end of the 25 years. This performance is only exceeded by the whole-house retrofit, which includes the effect of additional draughtproofing and an MVHR system, and achieves a maximum reduction of $54 \%$ relative to the baseline cumulative $\mathrm{CO}_{2}$ emissions.

\section{Early application of measures}

Despite dwellings $\mathrm{A}$ and $\mathrm{E}$ not achieving the greatest reduction in final annual energy consumption, the limited number of retrofit technologies are installed early on in the analysis period, and completed by years 5 and 3 respectively. This results in cumulative emissions comparable with, or better than, dwellings $\mathrm{B}$ and $\mathrm{C}$ despite smaller overall savings in annual energy consumption.
The Idealist restorers (dwelling A) had a preference for older dwellings, and were prepared to invest in reviving the original character of the building. Traditional dwellings may be less able to accommodate retrofit technologies (such as wall insulation due to architectural features), or may need higher cost measures (such as sash-in-case double-glazing to maintain the building's style). The dwelling purchased by this example persona required immediate action upon moving in, which results in lower cumulative emissions compared with other, more extensively retrofitted dwellings.

Similarly, the Property ladder persona (dwelling E) undertook a significant amount of work within the first three years of moving in; efficiency was not a driver of this process, however, and the simulation therefore takes advantage of a number of identified opportunities' to implement retrofit technologies, even though these were not actually undertaken by the householder.

\section{Delayed application of measures}

The Aesthetic Pragmatists (dwelling B) notably took action to address identified problems, but work did not commence on the home until after three years. The simulation of this timeline shows the negative implications of this delayed start: despite having marginally better annual energy performance than dwellings $\mathrm{A}$ and $\mathrm{E}$ from year 7 onwards, the cumulative emissions run on a higher trajectory until doubleglazing is installed in year 19 . 


\section{Variation in technology performance}

The information provided by EPCs and Energy Saving Trust advice (EST, 2013b) quote typical savings that an occupant can expect from energy-saving measures. The simulations indicate that these values may vary depending on the installation sequence and the contributing factors are discussed here.

\section{Boiler upgrade}

Boiler efficiency presents the most obvious reason for the performance variations. An older boiler will consume more energy to satisfy a heating load than a new, more efficient one. Where the other retrofit technologies conserve energy by reducing the load on the heating system, the resulting step change in annual energy consumption will be greater under the operation of a less efficient boiler.

This is manifested by dwellings $\mathrm{C}$ and $\mathrm{E}$. The combined effect of installing loft insulation, doubleglazing, draughtproofing and ground floor insulation in dwelling C saves 13.61 MWh, where the dwelling retains the original boiler. However, the same measures installed in dwelling $\mathrm{E}$, after the replacement of the boiler in stage (i), save only $12.35 \mathrm{MWh}$ in annual energy consumption. This demonstrates that the annual energy savings realized by retrofit efforts to reduce space heating demand will be less for dwellings featuring a more efficient boiler, and consequently the payback of the measures will take longer.

\section{Presence of other measures}

On the basis of the previous discussion, the doubleglazing installed in dwelling B (after boiler replacement) would be expected to yield lower savings than that in dwelling A (before boiler replacement). This is not the case, however: dwelling B's reduction is 8.19 MWh and dwelling A's is 7.15 MWh despite the newer, more efficient boiler.

Inspection of the simulations shows that the combination of technologies reduces the space heating load and the total boiler operating hours. Installation of double-glazing in dwelling A reduces boiler operation by $441 \mathrm{~h}$ and in dwelling B by $1290 \mathrm{~h}$. This demonstrates the cumulative benefit realized from installing multiple retrofit technologies.

This variation in performance has implications for the Green Deal, as shown by Table 6. Based on a $£ 5000$ installation cost, glazing cannot meet the 'Golden Rule', therefore this analysis assumes an ECO contribution to reduce the loan value to $£ 2500$. This allows dwelling A to realize a marginal annual saving of $£ 1.29$ per annum once loan repayment costs have been deducted, which is only feasible based on a 25year loan at $7.3 \%$. The interest rates for the loan may be subject to variation, depending on the provider and how much money is being borrowed, however the example calculations on the gov.uk website assume values between $7.7 \%$ and $10.9 \%$ (DECC, 2013a).

The reduction in energy bills for dwelling $B$ is larger and goes considerably further in offsetting the cost

Table 6 Green Deal loan calculations for subsidised replacement glazing

\begin{tabular}{lcc}
\hline & A: Restorers & B: Aesthetic Pragmatists \\
\hline Cost of work & & $£ 5000^{\mathrm{a}}$ \\
Subsidised cost & $£ 2500$ \\
Remaining cost to household & $£ 2500$ \\
Interest rate & $7.3 \%$ & 25 years \\
Loan duration & $£ 220.36^{\mathrm{b}}$ \\
Annual repayment & $£ 5508.89$ \\
Total loan repayment & $3.1 \mathrm{p} / \mathrm{kWh}$ & \\
Unit cost of gas & & $8.19 \mathrm{MWh}$ \\
Annual energy saving from replacement glazing & & \\
Annual energy bill reduction & $7.15 \mathrm{MWh}$ & $£ 253.89^{\mathrm{c}}$ \\
Annual saving to customer & $£ 221.65^{\mathrm{c}}$ & \\
\hline
\end{tabular}

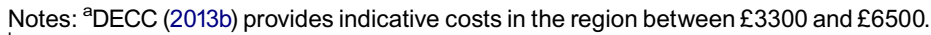

${ }^{\mathrm{b}}$ Repayment value was calculated by following the process applied by the illustrative examples provided on the gov.uk website (DECC, 2013a). ${ }^{\mathrm{c}}$ Based on the assumption that the improved glazing will reduce the space heating demand, the reduction in the energy bill is calculated relative to the unit cost of gas based on the values detailed in SAP (BRE, 2009). 
over the 25-year loan period. Any increase in the cost of natural gas will widen this difference in energy bill savings.

It should be noted that this calculation uses the energy saving values from the dynamic simulation for demonstration purposes, whereas the actual loan finance will be determined using the RdSAP methodology, adjusted to account for specific occupant parameters. Under this process, the glazing area is calculated based on a formula considering the dwelling form, total floor area and age of the dwelling. The E.ON Retrofit Test House can be considered to have 'more than typical' glazing due to the glazed patio doors in the dining room (consequently increasing the total glazed area by $25 \%$ ). Despite this increase, the calculated glazed area is still $19 \%$ below the actual measured glazed area. ${ }^{4}$ This underestimation will contribute to a reduction in the calculated benefits associated with installing better windows for this specific case study.

\section{Discussion}

It is worth reiterating that the purpose of this study was to identify the factors that influence the retrofit sequence and examine the implications on the operational energy consumption and $\mathrm{CO}_{2}$ emissions associated with the case study dwelling. It was not to identify an occupant persona most capable of reducing their annual energy consumption and cumulative $\mathrm{CO}_{2}$ emissions; the retrofit timelines derived from the example personas were for demonstrative purposes and should not be considered representative of the wider population. The results indicate that a case study dwelling can demonstrate significantly different results, most notably for cumulative effects. For example, dwellings $\mathrm{C}$ and $\mathrm{D}$ realize the same final annual energy consumption but demonstrate opposite extremes of cumulative $\mathrm{CO}_{2}$ emissions over a 25 -year period subject to the order and timing of installing retrofit measures.

\section{Motivations for retrofit}

The early application of retrofit technologies to reduce domestic energy consumption was critical to mitigating cumulative $\mathrm{CO}_{2}$ emissions. The interviews with the householders highlighted a number of factors affecting the ability of the occupants to undertake work prior, or subsequent, to moving into their new home:

- The Idealist restorer and Property Ladder Climber examples purchased their homes in recognition of the need to undertake immediate renovation work. This was a desirable characteristic for both, where the former relished the opportunity to revive the original character of the dwelling, and the latter identified a financial opportunity to improve the value of the property.

- Access to finance was an influential factor in determining the ability of the homeowner to proceed with efficiency improvements. The Functional Pragmatists were assisted by grant funding, and help from a family member to cover costs for the roof and replacement glazing respectively. Other homeowners were at a point in their life they could afford to invest in their home (Service Seekers), or had made a profit from renovating and selling their previous home (Property Ladder Climbers).

A desire to improve comfort was a repeatedly quoted reason behind much of the work undertaken by the householders, whereas redecoration was associated with many of the 'missed opportunities' to install retrofit measures. This suggests there might be significant potential to reduce $\mathrm{CO}_{2}$ emissions if energy saving measures can be more readily incorporated within minor refurbishments.

The motivations varied for the replacement the boiler: the existing boiler had failed; the boiler was replaced when central heating was installed; the capacity of the system needed to be increased; or the occupants acted on advice about the benefits of a more efficient boiler (and incidentally noted that savings were less than they had been led to believe). The boiler is a critical component of the building operation, and typically has a lifespan of 12 years (Shorrock, Henderson, \& Utley, 2005). It was observed that all the dwellings replaced their boilers at least once within the 25 -year period, which makes it an effective target to introduce efficiency measures. The mandatory requirement since 2005 for only condensing boilers to be installed is an example of a UK policy change that has already improved energy efficiency as part of refurbishment.

\section{Role of building regulations}

Home improvements contributing to increased heating requirements $(e . g$. the installation of central heating, conversion of a previously unheated space or the construction of an extension) will result in increased energy consumption and $\mathrm{CO}_{2}$ emissions. Whilst not considered for the purpose of the simulation exercise, this may present additional challenges to realizing the UK's 2050 carbon reduction target, especially when compounded by the expected increase in household numbers (ONS, 2011).

In England, upgraded building elements are expected to realize improved thermal properties, equal in performance to the minimum criteria specified for new dwellings (Table 7). U-values associated with new 
Table 7 Backstop U-values for new constructions, extensions and renovations in England

\begin{tabular}{|c|c|c|c|}
\hline \multicolumn{4}{|c|}{$\begin{array}{l}\text { Building Regulations: England } \\
\text { (ADL1B: Conservation of fuel and power in existing dwellings, 2010) }\end{array}$} \\
\hline \multirow{3}{*}{$\begin{array}{l}\text { Building } \\
\text { elements }\end{array}$} & New dwellings & \multicolumn{2}{|c|}{ Existing dwellings } \\
\hline & $\begin{array}{l}\text { Maximum }{ }^{\mathrm{a}} \text { area-weighted average; } U \text {-value for all } \\
\text { elements of the same type }\end{array}$ & $\begin{array}{l}\text { Standards for new thermal } \\
\text { elements }\end{array}$ & $\begin{array}{l}\text { Upgrading retained } \\
\text { thermal elements }\end{array}$ \\
\hline & \multicolumn{3}{|c|}{$\left(W / m^{2} . K\right)$} \\
\hline Walls & 0.30 & 0.28 & $0.30^{\mathrm{c}}$ \\
\hline Floor & 0.25 & 0.22 & 0.25 \\
\hline Pitched roof ${ }^{b}$ & 0.20 & 0.16 & 0.16 \\
\hline Windows & 2.00 & 1.6 & - \\
\hline
\end{tabular}

Notes: aNew dwellings may need to specify better $U$-values where the overall building design must demonstrate a better emission rating compared with a target emission rating (TER), which represents the minimum energy performance requirement for the dwelling.

${ }^{\mathrm{b}}$ Assumes insulation at ceiling level.

'Value for wall subject to external or internal insulation (i.e. not cavity insulation).

building elements associated with an extension (to an existing dwelling) are marginally more stringent due to the increased heating demand. The Scottish Building Standards, on the other hand, demonstrate much more onerous performance parameters (Table 8), particularly where the existing dwelling features minimal or no insulation. Upgraded building elements are expected to achieve the $U$-values in column (b), where the technical handbook states in many cases these can be achieved without technical risk, within the constraints of the existing construction' (Scottish Government, 2013).

The current regulations applicable in England demonstrate a limited capacity to drive energy refurbishments, where they only apply if significant work is being carried out on the dwelling (e.g. stripping the building element back to its structural components) (HM Government, 2010). Where this might have been achieved by consequential improvements, the

Table 8 Backstop U-values for new constructions, extensions and renovations in Scotland

\begin{tabular}{|c|c|c|c|}
\hline \multicolumn{4}{|c|}{$\begin{array}{l}\text { Building Regulations: Scotland } \\
\text { (Domestic Section } 6 \text { Energy, 2013 }\end{array}$} \\
\hline \multirow{4}{*}{$\begin{array}{l}\text { Building } \\
\text { elements }\end{array}$} & New construction & \multicolumn{2}{|c|}{ Extensions to existing constructions } \\
\hline & & \multicolumn{2}{|c|}{ Area-weighted average $U$-value for all elements of the same type } \\
\hline & $\begin{array}{l}\text { Maximum area-weighted } \\
U \text {-value for all elements of the } \\
\text { same type }\end{array}$ & $\begin{array}{c}\text { (a) Where wall } U \text {-value }> \\
0.7 \mathrm{~W} / \mathrm{m}^{2} . \mathrm{K} \text { and roof } U \text {-value }> \\
0.25 \mathrm{~W} / \mathrm{m}^{2} . \mathrm{K}\end{array}$ & $\begin{array}{c}\text { (b) Where parameters for column } \\
\text { (a) do not apply (or for upgraded } \\
\text { elements) }\end{array}$ \\
\hline & \multicolumn{3}{|c|}{$\left(\mathrm{W} / \mathrm{m}^{2} \cdot \mathrm{K}\right)$} \\
\hline Walls & 0.25 & 0.19 & 0.22 \\
\hline Floor & 0.20 & 0.15 & 0.18 \\
\hline Pitched roof ${ }^{b}$ & 0.18 & 0.13 & 0.15 \\
\hline Windows & 1.8 & 1.40 & 1.60 \\
\hline
\end{tabular}

Notes: The 2013 versions of the technical handbooks were laid before Parliament in May 2013, and came into force as of 1 October 2013; however, these values are also relevant for the 2010 version of the technical handbook.

${ }^{\mathrm{b}}$ Assumes insulation at ceiling level. 
application of this regulation continues to be restricted to a minimal number of dwellings with floor area greater than $1000 \mathrm{~m}^{2}$.

\section{Policy implications}

Karvonen (2013) suggests there is a mismatch between current policy and the way people live and behave in their homes. He identifies a number of factors that limit the uptake of efficiency measures, as perceived by homeowners: capital costs; uncertainty of final costs; the risk of problems developing after installation; aesthetic concerns; the impact on property value; and disruption and inconvenience during the installation process.

The UK government's Green Deal provides a loan to cover the cost of installing efficiency measures, addressing the first barrier identified by Karvonen, but does little to alleviate concerns regarding the others. The current study indicates that homeowners of similar dwelling types may experience varying abilities to qualify for the 'Golden Rule', or differences in energy bill savings, with respect to a given measure and the preceding technologies installed. This observation contrasts with the single value often used to indicate the 'potential savings' from installing an efficiency measures; e.g., the Home Energy Check (EST, 2014b) suggests that replacing wooden frame single-glazing with A-rated double-glazing will reduce annual energy bills by $£ 100$ for the E.ON Retrofit Test House. The discrepancy between potential and actual energy bill savings was highlighted by the interview participants representing the 'Functional Pragmatists' upon installing their new boiler, and could prove detrimental to the homeowner's trust in the available advice. Forum for the Future supported homeowners with undertaking energy efficiency work through provision of appropriate information, advice and some financial assistance for surveys, and actively encouraged community participation (Ross, 2011). They highlight that the development of trust in the process is of the upmost importance, as well as ensuring a positive experience for early adopters. The lack of clarity about the loan structure and associated costs associated with the Green Deal may go some way to explaining the coincidence of its launch with a $97 \%$ drop in the installation rate of cavity wall insulation (Pitt, 2013). This issue will have been exacerbated by increasing costs for retrofit technologies subject to the termination of subsidies when schemes such as Carbon Emissions Reduction Target (CERT) and Community Energy Saving Programme (CESP) came to an end (Table 1). Confidence in the proposed loan mechanism would be further degraded, where the application of a simplified, steady-state calculation (to determine the dwelling's EPC and Green Deal savings) presents a number of risks with respect to determining the details of a financial obligation: the household may not achieve the energy bill savings predicted by the calculations, or they may experience restricted access to funding for measures where the calculation indicates it does not qualify for the 'golden Rule'.

The interviews undertaken in this research highlight that energy efficiency was a lower priority than comfort and redecoration during refurbishment. There is strong evidence to suggest that public policy should provide greater incentive to implement efficiency measures during minor refurbishments or, as Karvonen (2013) suggests, integrating efforts within routine maintenance. These incentives might be financial, but could also include accreditation of the refurbishment labour force to ensure they are suitably skilled and motivated to offer energy-efficiency measures when undertaking other work. Coinciding these with identified 'trigger points' such as moving home (EST, 2011 b) provides greater opportunity to implement efficiency efforts sooner rather than later.

The use of evidence-based personas, drawn from the design domain, to represent householders provides an opportunity for multiple policies and technologies to be developed that meet particular needs. For example, Restorers could be targeted through minimum standards for work they carry out when upgrading their home, whereas Property Ladder Climbers may be targeted by incentives to encourage the uptake of a package of energy-efficient measures before moving in. The understanding and use of different personas enable a more targeted set of policies to be designed which can penetrate a greater range of the market, together with specific products that meet people's needs. The benefit of such an approach would be to improve the efficacy of policy measures, designed to address particular market sectors, resulting in an accelerated introduction of energy-efficiency measures as part of mainstream renovation practices.

\section{Conclusions}

The effects of retrofit measures were simulated for the energy and $\mathrm{CO}_{2}$ emissions of a case study dwelling, This was based on the phased application of retrofit measures actually undertaken by five types of home improvers. The following conclusions are drawn.

Immediate realization of significant energy reductions is critical to minimizing the cumulative emissions associated with the dwelling: early retrofit measures yield lower cumulative $\mathrm{CO}_{2}$ emissions than more extensive refurbishment efforts distributed over 25 years. This is important because $\mathrm{CO}_{2}$ emissions are long lived, remaining in the atmosphere for 5-200 years (IPCC, 2007); Archer (2009) suggests that once in the atmosphere $\mathrm{CO}_{2}$ will continue to affect the climate for thousands of years. Boardman (2007) highlights the 
importance of considering the cumulative emissions with respect to the overarching goal of an $80 \%$ reduction target in greenhouse gas emissions by 2050 . Calculations in 2009 (but since updated by other climate scientists) indicate that maintaining atmospheric concentration of $\mathrm{CO}_{2}$ at about $420 \mathrm{ppm}$ may help prevent global warming exceeding $2{ }^{\circ} \mathrm{C}$, and this would require total emissions, over the entire fossil era to be limited to $600 \mathrm{Gt} \mathrm{C}$; so far mankind has released about $300 \mathrm{Gt} \mathrm{C}$ (Archer, 2009). The principle is clear that immediate cuts in $\mathrm{CO}_{2}$ emissions will help to stabilize atmospheric $\mathrm{CO}_{2}$ sooner, thus permitting more time within which to develop alternative energy sources to fossil fuels (Archer, 2009).

Failure to realize these annual reductions in the initial years imposes a greater challenge for subsequent years, where larger reductions are needed to maintain cumulative emissions below the original target. This has important implications for policy, where historic performance will directly influence the determination of future interim targets.

The different personas identified in this study demonstrate that homeowners take very different approaches to home renovation and refurbishment, and the interviews show that energy efficiency is often not the main motivation behind home refurbishment. Significant life events or access to funding had strong influences on the work people undertook on their home. The development of future policy needs to understand better the motivations and barriers to energy retrofit, as perceived by homeowners. This may help to understand better the 'trigger points', such as moving home, where installation of efficiency measures can more easily be accommodated and so design better solutions to meet real needs.

A multipronged approach is therefore suggested with respect to developing future policy. This would enable a more appropriate variety of methods by which homeowners can be encouraged and incentivized to improve the energy performance of their home, relative to their personal circumstances. These may include: changes in the building regulations and standards; provision of grants or transparent finance mechanisms to assist with the costs of installation; or new and innovative methods that maintain energy efficiency at the forefront of people's thoughts, and targets opportunities that are likely to occur more frequently.

The current building regulations for dwellings in England are doing little to drive homeowners towards better standards of energy efficiency for the existing building stock. These need to be upgraded to encourage action during more minor refurbishments, in order to match the more stringent performance specifications considered feasible elsewhere in the UK. All five example personas had undertaken work that would require reference to the building regulations (in relation to replacement glazing, a conversion or extension, for example). This indicates a key opportunity to encourage greater improvement in energy performance across the housing stock.

Across all five example scenarios, 21 retrofit stages were considered, of which $62 \%$ took place within the first five years. Targeting new homeowners presents a number of opportunities by which to reduce energy consumption in the early years, thus reducing cumulative emissions throughout the occupation of the dwelling. 'Restorers', 'Service Seekers' and, to some extent, 'Property Ladder Climbers' were prepared to endure significant disruption (or temporarily live elsewhere) whilst work was undertaken on their new home. Much greater long-term benefits could be realized if more energy-efficiency measures could be incorporated at this stage (e.g. via mechanisms like the 'consequential improvements'). If Property Ladder Climbers become more experienced in installing energy-efficiency measures, and can link this to the benefits of the finished project, they are more likely to replicate this process on their next rung up the ladder.

The effect of individual technologies on a dwelling's operational performance can vary significantly according to the technologies already installed. This may have significant consequences for policies such as the Green Deal, where a loan to install efficiency measures is repaid through savings realized by the energy bill. This, in addition to the lack of clarity surrounding the loan mechanism, and the simplified calculation procedure, may diminish private homeowners' trust in the Green Deal, and compromise the success of the programme. The interview comments of the Functional Pragmatists demonstrate, however, that access to finance (via a grant or a family member) was key to enabling work to be undertaken on their home. Reliability and transparency represent critical characteristics of any future finance mechanisms aiming to encourage the future uptake of efficiency improvements.

An alternative approach may be to encourage efficiency improvements during routine maintenance or upgrades (e.g. replacement boiler installations). All this would give more opportunity to implement efforts prior to 2050 , and maintain energy conscious behaviour at the forefront of people's minds. This may represent a more effective mechanism by which to target the Aesthetic and Functional Pragmatists, who tended to take action as and when they identified problems.

\section{Acknowledgements}

This research was undertaken at Heriot-Watt and Loughborough universities. For further information 
on the CALEBRE Project, contact Dennis Loveday (e-mail: d.l.loveday@lboro.ac.uk). The full set of personas is available on request from Victoria Haines (e-mail: v.j.haines@lboro.ac.uk). Access to the underlying research data presented in this paper is restricted as participants may be identifiable.

\section{Disclosure}

The authors received no financial interest or benefit arising from the direct applications of this research.

\section{Funding}

This work was supported by the Research Councils UK Energy Programme and E.ON [grant number EP/ G000387/1], to whom the authors express their gratitude.

\section{References}

Archer, D. (2009). The long thaw, How humans are changing the next 100,000 years of Earth's climate. Princeton and Oxford: Princeton University Press. Epilogue, 162.

Banfill, P. F. G., Simpson, S. A., Loveday, D. L., \& Vadodaria, K. (2013a). Briefing note 2: MVHR systems and airtightness improvements in domestic refurbishment. In D. L. Loveday \& K. Vadodaria (Eds.), Project CALEBRE: Consumer appealing low energy technologies for building retrofitting: A summary of the project and its findings (pp. 8-10). Loughborough, UK: Loughborough University.

Banfill, P. F. G., Simpson, S. A., Loveday, D. L., \& Vadodaria, K. (2013b). Briefing note 3: Impact of the order of domestic retrofit on long term energy and carbon savings. In D. L. Loveday and K. Vadodaria (Eds.), Project CALEBRE: Consumer appealing low energy technologies for building retrofitting: A summary of the project and its findings (pp. 1114). Loughborough, UK: Loughborough University.

Boardman, B. (2007). Home truths: A low-carbon strategy to reduce UK housing emissions by $80 \%$ by 2050 (ECI research report 34). Oxford: University of Oxford's Environmental Change Institute.

BRE. (2009). Standard assessment procedure for energy rating of dwellings. Retrieved from Standard Assessment Procedure (SAP 2009) http://www.bre.co.uk/sap2009.

Building.co.uk. (2013). White papers: 07/Sustainability. Retrieved from: Sustainability White Paper: http://www. building.co.uk/home/white-papers/sustainability-white-pap er/5030465. article

DCLG. (2013). English housing survey: Homes - Annual report on England's housing stock, 2011. London: Department for Communities and Local Government.

DECC. (2013a). Examples of how green deal finance could work in practice. Retrieved from How Green Deal finance could work in practice https://www.gov.uk/government/ publications/how-green-deal-finance-could-work-in-practice

DECC. (2013b). Green deal: Energy saving for your home or business. Retrieved from Green Deal energy saving for your home www.gov.uk/green-deal-energy-saving-measures.

DECC. (2014a). Overall energy consumption in the UK since 1970. In Energy consumption in the United Kingdom. Retrieved from: https://www.gov.uk/government/uploads/ system/uploads/attachment_data/file/337452/ecuk_chapter_ 1_overall_factsheet.pdf
DECC. (2014b). Domestic energy consumption by end use 1970 to 2013: Table 3.04. Retrieved from https://www.gov.uk/ government/uploads/system/uploads/attachment_data/file/ 375388/domestic.xls

DECC. $(2014 \mathrm{c})$. Renewable heat incentive and renewable beat premium payments quarterly statistics, March 2014 Retrieved from https://www.gov.uk/government/uploads/ system/uploads/attachment_data/file/305438/Renewable_He at_Incentive_and_Renewable_Heat_Premium_Payments_qu arterly_statistics_March_2014.pdf

Earl, P. E., \& Peng, T. (2011). Home improvements. In S. Cameron (Ed.), Handbook on the economics of leisure (pp. 197-220). Cheltenham: Edward Elgar Publishing Limited.

EST. (2006). Domestic Energy primer: An introduction to energy efficiency in existing homes. Retrieved from www.southend. gov.uk/.../id/416/energy_efficiency_introductory_guide

EST. (2007). CE83 energy-efficient refurbishment of existing housing. London: Energy Saving Trust.

EST. (2008). Energy efficiency in hard to treat homes. Retrieved from http://www.energysavingtrust.org.uk/business/Busine ss/Information-centre/Publications-and-Report-Library/Pub lications-and-Case-Studies

EST. (2009). Hard to treat homes. Retrieved from http://www. energysavingtrust.org.uk/business/Business/Housing-profess ionals/Interactive-tools/Hard-to-treat-homes

EST. (2011a). Sustainable refurbishment (2010 edition). Energy Saving Trust. Retrieved from http://www.energysavingtrust. org.uk/Publications2/Housing-professionals/Refurbishment/ Sustainable-Refurbishment-2010-edition.

EST. (2011b). Trigger points: a convenient truth. Retrieved from http://www.energysavingtrust.org.uk/Publications2/Corpor ate/Research-and-insights/Trigger-Points-a-convenient-truth

EST. (2013a). Green Deal and ECO. Retrieved from http://www. energysavingtrust.org.uk/Take-action/Find-a-grant/Green-De al-and-ECO

EST. (2013b). Improve your home. Retrieved from http://www. energysavingtrust.org.uk/Take-action/Improve-your-home

EST. (2014a). Feed-in tariff scheme. Retrieved from http://www. energysavingtrust.org.uk/domestic/content/feed-tariff-scheme

EST. (2014b). Home energy check. Retrieved from http://www. energysavingtrust.org.uk/domestic/content/home-energy-check

Fawcett, T. (2014). Exploring the time dimension of low carbon retrofit: Owner-occupied housing. Building Research and Information, 42(4), 477-488. doi:10.1080/09613218. 2013.804769

Fawcett, T., \& Mayne, R. (2012, January 24th - 26th). Exploring an 'over time' model of eco-renovation. In Retrofit 2012 Conference. Salford, UK.

Gillott, M., Loveday, D. L., \& Vadodaria, K. (2013). Briefing note 1: Airtightness improvements and ventilation systems in domestic refurbishment. In D. L. Loveday \& K. Vadodaria (Eds.), Project CALEBRE: Consumer Appealing Low Energy technologies for Building Retrofitting: A summary of the project and its findings (pp. 4-7). Loughborough, UK: Loughborough University.

Gov.UK. (2012). Helping households to cut their energy bills. Retrieved from https://www.gov.uk/government/policies/ helping-households-to-cut-their-energy-bills/supporting-pag es/warm-front-scheme.

Gov.UK. (2014). Increasing the use of low-carbon technologies. Retrieved from https://www.gov.uk/government/policies/ increasing-the-use-of-low-carbon-technologies/supporting-pa ges/renewable-heat-incentive-rhi.

Gov.UK. (n.d). Green deal: Energy saving for your home. Retrieved from https://www.gov.uk/green-deal-energy-saving-measures/ overview

Goodwin, K. (2010). Designing for the digital age: How to create buman-centred products and services. Indianapolis: Wiley Publishing.

Haines, V. J., \& Mitchell, V. A. (2014). A persona-based approach to domestic energy retrofit. Building Research and Information, 42(4), 462-476. 
Haines, V. J., Mitchell, V. A., \& Mallaband, B. (2010, October). Using a practice-orientated approach to inform the design of energy-efficiency measures for older homes. In ERSCPEMSU conference proceedings, Delft \& Cape Town, 25-29.

Haines, V. J., Mitchell, V. A., \& Mallaband, B. (2012). Merging a practice-orientated approach with an engineering-driven product development: a case study on home improvement. Journal of Design Research, 10(1/2), 28-49. doi:10.1504/ JDR.2012.046138

HM Government. (2008). Climate change act 2008 (c. 27). UK: Her Majesty's Stationary Office Ltd.

HM Government. (2010). Approved document L1B: Conservation of fuel and power in existing dwellings. London: NBS.

IES. (n.d.) integrated environmental solutions virtual environment [Computer software]. Integrated Environmental Solutions Limited.

IPCC. (2007). Working group I: The scientific basis. Retrieved from http://www.ipcc.ch/ipccreports/tar/wg1/016.htm\#tab TechSum1

Judson, E. P., \& Maller, C. (2014). Housing renovations and energy efficiency: Insights from homeowners' practices. Building Research and Information, 42(4), 501-511.

Karvonen, A. (2013). Towards systemic domestic retrofit: A social practices approach. Building Research \& Information, 41(5), 563-574. doi:10.1080/09613218.2013.805298

Mallaband, B., Haines, V., \& Mitchell, V. (2013, 27th April 2nd May). Exploring past home improvement experiences to develop future energy saving technologies. In Methods for studying technology in the home workshop, ACM SIGCHI Conference on Human Factors in Computing Systems (CHI), Paris, France.

Mallaband, B., Haines, V. J., \& Mitchell, V. A. (2012). Barriers to domestic retrofit - Learning from past home improvement experiences. In: Retrofit 2012 Conference. Salford, UK, January 24th - 26th, 2012.

Marshall, M. N. (1996). Sampling for qualitative research. Family Practice, 13(6), 522-526.

McKay, E. (2013). UI is communication: How to design intuitive, user centered interfaces by focusing on effective communication. San Francisco, CA: Morgan Kaufmann.

Mulder, S. \& Yaar, Z. (2006). The user is always right: A Practical Guide to Creating and Using Personas for the Web (Voices That Matter). Berkeley, CA: New Riders.

Ofgem. (2013a). The final report of the community energy saving programme (CESP) 2009-2012, May 2013. Retrieved from https://www.ofgem.gov.uk/ofgem-publications/58763/cespfinal-report-2013final-300413.pdf

Ofgem. (2013b). The final report of the carbon emissions reduction target (CERT) 2008-2012, May 2013. Retrieved from https://www.ofgem.gov.uk/ofgem-publications/58425/ certfinalreport2013300413.pdf

Ofgem. (n.d). Energy companies obligation (ECO). Retrieved from https://www.ofgem.gov.uk/environmental-programm es/energy-companies-obligation-eco

ONS. (2011). Summary: UK population projected to reach 70 Million by Mid 2027. Retrieved from http://www.ons.gov. uk/ons/dcp171780_240701.pdf

Palmer, J., \& Cooper, I. (2012). United Kingdom housing energy fact file 2012. London: Department of Energy and Climate Change.

Pitt, V. (2013). Cavity wall installations collapse under green deal. http://www.building.co.uk/sustainability/sustainabili ty-news/cavity-wall-installations-collapse-under-green-deal/ 5055444.article

Ross, B. (2011). Refit West: Update from the front line. London: Forum for the future, Retrieved from: http://www. forumforthefuture.org/sites/default/files/project/downloads/ refitwestupdatefromthefrontline.pdf

Scottish Government. (2013). Technical handbooks 2013 domestic - Energy. Retrieved from: http://www.scotland.gov. uk/Topics/Built-Environment/Building/Building-standards/ publications/pubtech/th2013dom6

Shorrock, L., Henderson, J. \& Utley, J. (2005). Reducing carbon emissions from the UK housing stock. Watford: BRE. Retrieved from http://projects.bre.co.uk/PDF_files/Reducing CarbonEmissionsHousingv3.pdf

Simpson, S. A., \& Banfill, P. F. G. (2012, January 24th - 26th). The importance of the order of installation of retrofit measures in optimising long term energy and $\mathrm{CO}_{2}$ reductions. In Retrofit 2012 Conference, Salford, UK.

Vadodaria, K., Loveday, D., Haines, V., Mitchell, V., Mallaband, B. \& Bayer, S. (2010). UK solid-wall dwellings - Thermal comfort, Energy efficiency refurbishment and the user perspective - Some preliminary analysis from the CALEBRE project. In Proceedings of adapting to change: New thinking on comfort. 9-11 April, Cumberland Lodge, Windsor, UK.

Wright, A. (2008). What is the relationship between built form and energy use in dwellings?. Energy Policy, 36(12), 4544-4547. doi:10.1016/j.enpol.2008.09.014

Zero Carbon Hub. (2013). Zero carbon strategies for tomorrow's new homes. Retrieved from http://www.zerocarbonhub.org/ resourcefiles/ZeroCarbonStrategies_web.pdf

\section{Endnotes}

${ }^{1}$ Based on an SAP 2005 calculation.

${ }^{2}$ Based on installations of cavity-wall insulation in April 2013, relative to the same month the previous year.

${ }^{3}$ The CALEBRE project (http://www.lboro.ac.uk/microsites/ enterprise/calebre/) is an E.ON/Research Councils UK-funded research project involving a partnership of six leading UK universities, led by Loughborough University. Over 4.5 years (October 2008-April 2013), CALEBRE investigated a selection of technologies, specifically from the perspective of domestic refurbishment. These technologies ranged from the well known (heat pumps and MVHR) through to new and emerging (vacuum glazing) and on to blue skies (advanced surface treatments). Alongside these, the project gathered important insights into consumer perspectives surrounding refurbishment. This paper brings together research from across the CALEBRE project relating to refurbishment and consumer preference.

${ }^{4}$ Based on a typical glazing assumption, RdSAP determines a total window area of $19.02 \mathrm{~m}^{2}$ for a 1930s' house with total floor area of $99.5 \mathrm{~m}^{2}$. Where the dwelling has 'more than typical' glazing, the assumed window area is increased by $25 \%$ to $23.77 \mathrm{~m}^{2}$. The actual glazing of the E.ON Retrofit House measures $29.28 \mathrm{~m}^{2}$ (including glazed doors), therefore the RdSAP assumed value falls short by $19 \%$. 